University at Buffalo School of Law

Digital Commons @ University at Buffalo School of Law

Journal Articles

Faculty Scholarship

$1-1-1984$

\title{
Critical Legal Studies: An Afterword
}

John Henry Schlegel

University at Buffalo School of Law

Follow this and additional works at: https://digitalcommons.law.buffalo.edu/journal_articles

Part of the Legal Education Commons, and the Legal Studies Commons

\section{Recommended Citation}

John H. Schlegel, Critical Legal Studies: An Afterword, 36 Stan. L. Rev. 673 (1984).

Available at: https://digitalcommons.law.buffalo.edu/journal_articles/716

\section{C) ${ }_{\text {COPYRIGHT }}^{\text {N }}$}

This Article is brought to you for free and open access by the Faculty Scholarship at Digital Commons @ University at Buffalo School of Law. It has been accepted for inclusion in Journal Articles by an authorized administrator of Digital Commons @ University at Buffalo School of Law. For more information, please contact lawscholar@buffalo.edu. 


\section{Gritical Legal Studies: An Afterword}

\section{John Henry Schlegel}

\section{. . . where ignorant armies clash by night.*}

The patient reader who has struggled through this symposium may feel lots of things-weariness verging on boredom perhaps, interest maybe, delight hopefully. Some, however, will have a lingering feeling much like Arnold on that beach-a sense of things going on, of disputes obscure to outsiders, somehow hidden from view by darkness or fog or smoke. That feeling is, I suggest, not necessarily the after-image of a bedazzled brain. It is real because something is going on in each piece that is hidden from view and that ought to be brought to light, to be made the subject of critical thought.

For a historian of American Legal Realism, the necessary analogy is to is the Great Realist Debate. As the story is usually told, one day Roscoe Pound decided that he had to speak out about some disquieting tendencies in the scholarship and thought of "some of our younger teachers of law," which provoked Llewellyn to reply denying Pound's charges. While the event was more complicated than that, the aftermath of the event is clear. A new cottage industry was born: the making of handcrafted definitions of what Realism really was. Were one to carefully review the product of this industry, one would be struck with a deep sense of wonder about what was at stake in the underlying dispute. What turf-intellectual, political, moral, or even personal (in terms of control of an intellectual movement)was implicated by the answer given to the question "What was Realism?" so that anyone would fight about it?

How one answers that question about Realism is of little importance to the issues raised by this Symposium. What is important is to recognize that, as was the case with Realism's cottage industry, in each of these pieces there is an implicit or explicit definition of Critical Legal Studies. Both adherents to and critics of CLS offer these definitions which are by no means all the same. Mine ${ }^{1}$ is not

* M. ArNoln, Dover BeAch (London 1867).

1. Schlegel, Notes Toward an Intimate, Opinionated, and Affectionate History of the Conference on Critical Legal Studies, 36 STAN. L. REv. 391 (1984). 
Gordon's, ${ }^{2}$ and his is not Trubek's, ${ }^{3}$ for example. Each definition has the necessary property of including some things and excluding others. Each definer thus exercises a choice about what to include and what to exclude. That is the burden of one strand of Critical thought. There are no socially necessary categories; choice must always be exercised when ordering the world. Thus one may say that this entire batch of scholarship is at bottom a fight about a definition, about what Critical Legal Studies is. When one sees such a fight, one ought to wonder what is at stake in it. It cannot be truth, for there is no choice to truth. What, then, is at issue that would make me define Critical Legal Studies socially and Gordon define it intellectually? That would cause Trubek to give a different intellectual definition than both Gordon's and Ted White's?

I do not think it profitable for me to answer this question. My answer would only begin an infinite regress. But by the same token, I think it is important to recognize that it is these battles over definition with their entrances, exits, alarms, and fires that one perceives but dimly through the darkness or fog or smoke. Perhaps those who are persuaded that CLS has something to offer to legal thought will find it appropriate to turn their new method to the question of what this occluded battle is about.

2. Gordon, Critical Legal Histories, 36 STAN. L. REv. 57 (1984).

3. Trubek, Where the Action is: Critical Legal Studies and Empiricism, 36 STaN. L. Rev. 575 (1984).

4. White, The Inevilability of Critical Legal Studies, "6 STAN. L. REv. 649 (1984). 